UDC 81'373; 001.4 81'38; 801.6; 808

DOI https://doi.org/10.24919/2308-4863/36-1-21

Rajab JAFARLI,

orcid.org/0000-0002-1375-4034

Senior Lecturer, Head of the Department of Foreign Languages

Nakhchivan University

(Nakhchivan,Azerbaijan)r.jafarli@nu.edu.az

\title{
STYLISTIC DIFFERENTIATION OF ENGLISH LEXICON IN THE CONTEXT OF LITERARY LAYER (POETICS, TERMS, ARCHAISMS, FOREIGNISM, NEOLOGISMS)
}

The word stock of any language may be presented as a system elements of which are interconnected, interrelated and yet interdependent. Lexicology suggests many ways of classifying any vocabulary but for the purpose of stylistic analysis we may represent the whole word stock of English language as the domain divided into two major layers: the literary layer, the neutral layer and the colloquial layer.

The literary layer contain a number of subgroups, all of which have a certain property, characteristic of the layer on the whole, that is called an aspect. The aspect of the literary layer is its universal character. Spoken language, as it relates to everyday life, has a vocabulary that is used by a wide range of people, known and understood by everyone. Written language, on the other hand, has a more literary character due to its monologue nature, as well as the writer's correct adherence to language norms, and lexical units are used within semantic norms, and grammatical structure is given serious importance. In oral language, speech is mainly in the form of dialogues and is accompanied by gestures and facial expressions. Proper use of grammatical rules in this language, which has expressive and emotional features, does not play a significant role. Under the influence of these factors, both language forms give rise to their own characteristic and different lexical units. The vocabulary of the language changes and enriches under the influence of innovations in science, technology and culture, changes in economic, political and social life and other factors. This also leads to the richness of the language. The English language is also rich in scientific, technical, literary, political and philosophical ideas among the world's languages. As the vocabulary of a language develops with the entry of new words into the lexicon of the language and the transfer of these words to the main vocabulary of the language, some words and expressions in their structure lose their function and become obsolete. Poetic words or poetics are lexical units and belong to the artistic style and, especially when used in poems, increase the impact of the poem and strengthen its poetic tone by bringing it a special subtlety and sincerity. Poetics has more lyrical features than stylistic lexical shades.

Key words: lexicology, stylistic, classify, layer, neutral, colloquial, subgroup.

\author{
Раджаб ДЖАФАРЛІ, \\ orcid.org/0000-0002-1375-4034 \\ стариий викладач, завідувач кафедри іноземних мов \\ Нахічеванського університету \\ (Нахічевань, Азербайджан) r.jafarli@nи.еdи.аz
}

\section{СТИЛІСТИЧНА ДИФЕРЕНЦАЦІЯ АНГЛІЙСЬКОЇ ЛЕКСИКИ В КОНТЕКСТІ ЛІТЕРАТУРНОГО ШАРУ (ПОЕТИКА, ТЕРМІНИ, АРХАЇЗМИ, ІНТЕРНАЛІЗМИ, НЕОЛОГІЗМИ)}

\footnotetext{
Склад слів будь-якої мови може бути представлений у вигляді системних елементів, які взаємопов'язані та водночас взаємозалежні. Лексикологія пропонує багато способів класифікації будь-якого словникового запасу, але задля стилістичного аналізу ми можемо представити весь запас слів англійської мови як область, розділену на великі шари, такі як літературний шар, нейтральний шар та розмовний шар.

Літературний шар містить низку підгруп, кожна з яких має певну властивість, характерну для шару загалом, щзо називається аспектом. Аспектом літературного шару є його універсальний характер. Розмовна мова, щз стосується повсякденного життя, має словниковий запас, яким користується широке коло людей, відомий $i$ зрозумілий кожному. Натомість писемна мова має більш літературний характер завдяки своїй монологічній природi, а також правильному дотриманню письменником мовних норм, лексичні одиниці використовуються в межах семантичних норм, а граматичній структурі надається серйозне значення. В усній мові мова представлена переважно у формі діалогів і супроводжується жестами та мімікою. Правильне використання граматичних правил у иій мові, щзо має виразні та емоційні особливості, не відіграє суттєвої ролі. Під впливом ичих факторів обидві мовні форми породжують власну характеристику та різні лексичні одиниці. Словниковий запас мови
} 
змінюється та збагачується під впливом інновацій у науці, техніці та культурі, змін в економічному, політичному та соціальному житті та інших факторів. Це також приводить до багатства мови. Англійська мова також багата на наукові, технічні, літературні, політичні та філософські ідеї серед мов світу. У міру того, як словниковий запас мови розвивається з надходженням нових слів до лексикону мови та перенесенням цฺих слів до основної лексики мови, деякі слова та вирази в їх структурі втрачають свою функиію і застарівають. Поетичні слова, або поетика, є лексичними одиницями і належать до художнього стилю, особливо коли вони використовуються у віршах, посилюють вплив вірша та його поетичний тон, надаючи йому особливої тонкості та щиирості. Поетика має більще ліричних рис, ніж стилістичні лексичні відтінки.

Ключові слова: лексикологія, стилістика, класифікація, шар, нейтраль, розмовна мова, підгрупа.

Introduction. Dictionaries and the vocabulary of a language are the most valuable sources for seeing the worldviews, lifestyles, customs and traditions of peoples and nations, and for gaining insight into these concepts. Dictionaries are an invaluable source for tracking the socio-cultural change and development of peoples. The word "dictionnorim", which means "dictionary" in Latin, was first used by Bishop Salomon in the ninth century to mean "encyclopedia". John Garland first used the word "dictionnorim" in 1225 to mean "dictionary".

The vocabulary of the language changes and enriches under the influence of innovations in science, technology and culture, changes in economic, political and social life and other factors. This also leads to the richness of the language. The English language is also rich in scientific, technical, literary, political and philosophical ideas among the world's languages. As the vocabulary of a language develops with the entry of new words into the lexicon of the language and the transfer of these words to the main vocabulary of the language, some words and expressions in their structure lose their function and become obsolete. The division of a language into two groups, written and oral, also affects the vocabulary of the language. As a result of this division, some words and expressions retain their existence in the oral language, while others continue to maintain their existence in the written language (Dille, 2005a).

Spoken language, as it relates to everyday life, has a vocabulary that is used by a wide range of people, known and understood by everyone. Written language, on the other hand, has a more literary character due to its monologue nature, as well as the writer's correct adherence to language norms, and lexical units are used within semantic norms, and grammatical structure is given serious importance. In oral language, speech is mainly in the form of dialogues and is accompanied by gestures and facial expressions. Proper use of grammatical rules in this language, which has expressive and emotional features, does not play a significant role. Under the influence of these factors, both language forms give rise to their own characteristic and different lexical units.

Discussion. The vocabulary of any language can be presented as an interconnected and at the same time interdependent system element. Lexicology offers many ways to classify a dictionary in any language, but for the purpose of stylistic analysis we can classify the vocabulary of English by dividing it into three main layers. These are the formal (standard), neutral and informal (nonstandard) layers. The Shorter Oxford English Dictionary, published in 1973, developed a diagram to describe the layers in the English dictionary. According to this diagram, the following is included in the literary layer:

Poetic words or poetics are lexical units and belong to the artistic style and, especially when used in poems, increase the impact of the poem and strengthen its poetic tone by bringing it a special subtlety and sincerity. Poetics has more lyrical features than stylistic lexical shades. Poetic words add a poetic nuance to ordinary concepts, and their use is largely limited to the style of poetry and is monosemantic in nature. Poetic words are very limited in number. Although romantic languages such as Portuguese and French are famous for their aesthetically pleasing words and expressions, such words have a special place in the English lexicon and add aesthetics to the language. The following expressions can be given as examples of poetic words in the English lexicon.

Aesthete is a person who is especially sensitive to beauty in art. "Despite the occasional nostalgia, Mr. McGee is too much of an aesthetic to wallow in the doldrums for long, and his enthusiasm is contagious" (Kean, 2020).

Scintilla is a spark, a trace. The word is derived from Latin and is used figuratively in English to mean shine, spark, trace. "Here is not a scintilla of evidence that this is true" (Leonardi, 2020).

Aurora is the phenomenon of light, consisting of currents visible in the upper layer of the magnetic polar regions of the planet, polar lights. "The aurora forecast tries to predict what the sun might do" (Krakow, 2020).

Terms. The words related to this layer include not only scientific terms, but also terms that have appeared in any technique or in various fields of art. Terms are words and phrases that express a more scientific concept than other layers. The terms can be divided into several groups according to their etymological nature. 
These are terms formed under the influence of Greek, Latin, French, German and other foreign sources or languages. For example, terms such as "botany, anatomy, schedule" are of Greek origin and still exist in English. Terms such as "locomotive, chivalry, march, estate" are of Latin origin, terms of French origin, such as "facade, renaissance, maneuver, squad, cliché", German terms such as "cobalt, zinc, quartz" have become common words in English. One of the main features of the terms is their variable quality, as new terms are easily created; old ones are replaced and put into use (Galperin, 2005a). This sensitivity to change is mainly due to the need for linguistic reflection of the cognitive process that scientists continue to use in the analysis of different concepts and events. The term is directly related to the concept it expresses, in other words, it focuses on an important quality of mental activity or action. They are mostly used in special works that touch on the concepts of some fields of science, and thus belong to the style of scientific language.

Although the terms are stylistically neutral, they can be used for this purpose. In any story or poem, terms can have a special expressive and emotional meaning. For example, M. Wilson uses technical terms in his poem "Live with Lighting" when creating a portrait of his hero, who is a nuclear physicist, and presenting it to his readers. Given the rapid changes in science and technology, and the fact that English, as an international language, plays an important role in this area, some terms lose their original character and quality in this language and gradually become common words. This process is called "de-termination". Words like radio, television, computer, network are examples of it.

Archaisms (archaic, obsolescent and obsolete words) are words that are obsolete or not used in modern speech because they have appropriate synonyms. Archaisms can also be words that are often not synonymous, because the concepts expressed by these words have no meaning in modern life, and thus become archaic and out of circulation. In English lexicology, archaisms are also indicated by the terms "old" and "obsolete words". The meanings of these words are understandable, but they are almost never used. One of the main reasons for the emergence of archaisms is the development of language and the renewal of the lexicon under the influence of this factor. In April 1755, the famous English lexicographer Samuel Johnson published a two-volume dictionary of the English language. By this time, more than twenty English dictionaries had been published, but this dictionary, developed by S. Johnson, differed in many respects. Robert Burchfield, a modern Eng- lish lexicographer, notes that this dictionary, developed by Johnson, went down in history as the only dictionary compiled by a single writer. Johnson's dictionary was published in two forms. The first was the folio volume, published in 1755, and the octave volume, published in 1756 (Hayakawa, 2008a). In both of these editions, a large number of archaic words have been published. If we look at both publications, one of the important differences between them is the reduction in the number of archaic words. Johnson developed the octova volume based on the folio volume and reduced the number of archaic words in this new volume. It is difficult to say that all these changes were made by the author during the preparation of the second edition, but to make the second edition more compact and simple, some etymological abbreviations, long references and unnecessary usage notes, as well as some archaic words were removed (Hayakawa, 2008b).

Barbarism and foreign words. These words are of foreign origin, not fully assimilated into the English language. These words are also considered derivative words and do not belong to the literary language. Most barbarisms have English equivalents or synonyms (chic - stylish, bon mot - clever, ad finitum - to infinity, beau monde - high society). Distinguishing barbarisms and foreign words is very important in terms of style. Barbarism has already become a reality of the English language and is reflected in dictionaries, although used for certain stylistic purposes; foreign words do not belong to the vocabulary of the English language and are not registered by dictionaries. Some foreign words perform a terminological function: ukas, udarnik, kolkhoz, solo, tenor, blitzkrig, luftwaffe, and the terminology is not synonymous. Barbarisms and foreign words have the function of describing local nuances inherent in tradition, concrete facts and events. Among these concepts, barbarism retains its power due to its characteristics as a means of individualization and typification. With the help of these lexical units, the writer can describe the typical features, psychology, language features, socio-class position and other features of the characters in the work of art (Dille, 2005b).

$\mathrm{XV}$ century is known in Europe as the Renaissance. During this period, interest in Roman and Greek literature began to grow in Europe. Looking at the etymology of the borrowed words, it is clear that in the first half of the 16th century, the English people began to establish and develop relations with other peoples. New words have been added to the vocabulary of the language in connection with innovations and achievements in trade, health, literature and other fields. The most important collaborations were estab- 
lished through the Romance and Germanic languages (Расторгуева, Жданова, 1972).

The main language that influenced English was French. Looking at the history of English, it seems that the language used in English palaces between the 9th and 14th centuries was much more influenced by French. The royal family, as well as the nobility, spoke French. Under the influence of these factors, a large number of words of French origin were added to the English dictionary. Ballet is a world-famous dance of French origin. It has taken its place in the English lexicon. The word retains its pronunciation in French. The letter " $t$ " at the end of the word is not pronounced and the last syllable is pronounced as "ley". A number of words of French origin, such as "buffet", "gourmet", "fillet", "chalet" entered the English dictionary. Words of French origin, such as "cafe", "croissant", "entrepreneur", "genre", "rendezvous" are included in the English dictionary (https://www.eng-literature.com/2017/06/11-frequently-used-swear-vulgar-words-english-communication.html).

Other words that make up the majority of the English dictionary are words of German origin. Many of these words are associated with scientific and cultural achievements. In the 16th century, Germans were brought to England to work in the mines. Terms related to mineralogy and geology began in the 16th century and became more widespread in the 18th century. Most German derivations are not just terminological. Later, many words were added to the English lexicon. This applies to most philosophical and political terms. A number of words, such as "gestapo", "glitch", “klutz”, "bunker”, "kinderkarten”, "delicatessen", "rucksack", "schmooze", have taken their place in the English lexicon as words of German origin (https://www.eng-literature.com/2017/06/11-frequently-used-swear-vulgar-words-english-communication.html).

After Columbus discovered America in the late 15th century, Europeans began to flock to the continent, and Spain became one of the richest countries in Europe after the excessive colonization of America. At a time when the British navy was strengthening, the two countries began to establish close ties.
Already in the XVI - XVII centuries, agreements on trade, politics and weapons were concluded, and in connection with this, various words were added to the English dictionary. "Parade", "grenade", "guerilla" military and naval terms were included in the English dictionary. "Plaza", "cargo", "embargo", "sherry" commercial terms, "patio", "guitar", "matador", "macho", "junta" and other words of Spanish origin entered the lexicon as a foreign word that people also use in everyday speech (https://www.eng-literature.com/2017/06/11-frequently-used-swear-vulgar-words-english-communication.html).

From all this, it can be concluded that the inclusion of new words and expressions in the vocabulary of the language, the acquisition of new meanings of words and other linguistic changes engraved and strengthened the historical traces of the English people in the dictionary. Derived words did not hinder the originality and independence of the language; on the contrary, it led to its development and enrichment.

The vocabulary of a language is constantly changing, and this feature is an indicator of the uniqueness of each language. One of the important reasons for these changes is the emergence of new concepts in science and technology, changes in social and cultural life. These factors lead to the enrichment of almost all languages. The English language, which constantly adds words to the vocabulary, has added to its lexicon the neologisms formed under the influence of the above-mentioned factors.

Neologism was first used as a term in French in 1755. Later, in the 1800s, it was used in English to mean "the use of new words, innovations in language".

Conclusions. Neologisms are formed either by the influence of innovations in science and technology, or by adding new meanings to words in the lexicon. There are some factors that affect the stabilization of neologisms in English. The most important of these factors is that they are treated in the language as shortterm and transient lexical units. I. R. Galperin notes that neologisms enter the vocabulary of the language very quickly and unexpectedly. And these words are not immediately reflected in dictionaries, which creates difficulties in translation (Galperin, 2005b).

\section{BIBLIOGRAPHY}

1. Leonardi A. Washington Examiner. Shepard Smith cuts off Trump press conference for 'absolutely untrue' claims about election. 5 Nov. 2020.

2. Dille C. The Dictionary in abstract: Johnson's abridgments of the Dictionary of the English Languagefor the common reader. Anniversary Essays on Johnson's Dictionary. Cambridge : Cambridge University Press, 2005. 199 p.

3. GU, J. LU, S. Language and Culture. Shanghai : Shanghai Foreign Language Education Press, 2002. 208 p.

4. Hayakawa I. Obsolete Words and Meanings in Johnson's Dictionary. 2008.

5. Krakow M. Anchorage Daily News. Look up, Alaska : The aurora is expected to be especially active this week, 21 Oct. 2020. 
6. Kean S. Nose Dive. Review : Olfactory Bliss. 22 Oct. 2020.

7. Galperin, I. R. İngiliz dili tarzı üzerine yazılar. M. : Yabancı dilde edebiyat yayınevi, 2005.

8. Расторгуева Т. А., Жданова И. Ф. History of the English language. Москва : Высшая школа, 1972, $175 \mathrm{~s}$.

9. İngilizceye başka dillerden gelmiş olan sık kullanılan İngilizce yabancı kelimeler. URL: https://www.fluentu.com/ blog/english-tur/ingilizce-yabanci-kelimeler.

10. 11 Frequently used swear or vulgar words for English communication. URL: https://www.eng-literature. com/2017/06/11-frequently-used-swear-vulgar-words-english-communication.html.

\section{REFERENCES}

1. Anthony Leonardi, Washington Examiner, "Shepard Smith cuts off Trump press conference for 'absolutely untrue' claims about election", 5 Nov. 2020.

2. Catherine Dille. "The Dictionary in abstract: Johnson's abridgments of the Dictionary of the English Language for the common reader", in Anniversary Essays on Johnson's Dictionary (Cambridge University Press, 2005, p. 199).

3. GU, J. LU, S. Language and Culture. Shanghai: Shanghai Foreign Language Education Press. 2002. 208 p.

4. Isamu Hayakawa. "Obsolete Words and Meanings in Johnson's Dictionary", 2008

5. Morgan Krakow, Anchorage Daily News, Look up, Alaska: The aurora is expected to be especially active this week. 21 Oct. 2020.

6. Sam Kean. Nose Dive 'Review: Olfactory Bliss. 22 Oct. 2020.

7. Galperin I. R. İngiliz dili tarzı üzerine yazılar [Inscriptions on the style of the English language] I. R. Halperin. M.: Literature publishing house in a foreign language, 2005. [in Russian].

8. Rastorgueva T. A., Zhdanova I. F. [History of the English language]. Moskva: Higher school, 1972, 175 p. [in Russian].

9. İngilizceye başka dillerden gelmiş olan sık kullanılan İngilizce yabancı kelimeler. [Common English foreign words that have come to English from other languages]. https://www.fluentu.com/blog/english-tur/ingilizce-yabanci-kelimeler [in Turkish].

10. 11 Frequently used swear or vulgar words for English communication. https://www.eng-literature.com/2017/06/11frequently-used-swear-vulgar-words-english-communication.html. 